\title{
HUBUNGAN MOTIVASI KERJA DENGAN KINERJA GURU PENDIDIKAN JASMANI OLAHRAGA DAN KESEHATAN DALAM PENGELOLAAN PEMBELAJARAN
}

\author{
Oleh: \\ Nurul Ihsan ${ }^{1}$, Asep Sujana Wahyuri ${ }^{2}$, Muhammad Aripin $\mathrm{S}^{3}$ \\ Jurusan Pendidikan Olahraga, Fakultas IImu Keolahragaan \\ Universitas Negeri Padang
}

\begin{abstract}
Abstrak: Penelitian ini bertujuan untuk mendapatkan informasi tentang hubungan motivasi kerja dan kinerja guru Pendidikan Jasmani Olahraga dan Kesehatan dalam mengelola pembelajaran.penelitian dilakukan pada jam sekolah setelah pembelajaran pendidikan jasmani olahraga dan Kesehatan di Sekolah Dasar Negeri Kabupaten Padang Kota Padang Utara. Populasi dalam penelitian ini adalah seluruh guru Pendidikan Jasmani Olahraga dan Kesehatan dan kepala sekolah. Sampel dalam penelitian ini berjumlah 50 responden teknik yang digunakan dalam penelitian ini adalah nonprobality sampling dimana seluruh anggota populasi dijadikan sampel.

Hasil dari penelitian ini menunjukkan 1) Motivasi guru memiliki hubungan positif dengan kinerja guru dalam mengelola pembelajaran penjasorkes di Sekolah Dasar Negeri Kabupaten Padang Kota Padang Utara, 2) semakin besar guru motovasi $(\mathrm{X})$ dengan kinerja guru $(\mathrm{Y})$ sebesar 62,40\%, hal ini berarti bahwa $62,40 \%$ variabel motivasi kerja guru $(X)$ memberikan hubungan dengan kinerja guru (Y) sebesar sisanya sebesar $37,60 \%$ dipengaruhi oleh variabel dan indikator lainnya.
\end{abstract}

Kata kunci: Motivasi Kerja, KInerja Gurudan Pengelolaan Pembelajaran

\section{PENDAHULUAN}

Pendidikan merupakan sebuah wahana untuk meningkatkan kualitas sumber daya manusia khususnya anak bangsa sebagai generasi penerus.Pendidikan juga merupakan suatu investasi bagi masyarakat dalam menata kehidupannya ke arah yang lebih baik.Pendidikan pada dasarnya adalah suatu proses untuk membantu manusia dalam mengembangkan dirinya. Selain itu, melalui pendidikan dapat dilahirkan individu-individu yang berpengetahuan, cakap, dan kreatif dengan mengembangkan potensi individu dari semua aspek baik kognitif, afektif maupun psikomotor.

Salah satu bagian integral yang tak dapat terpisahkan dari pendidikan umum adalah pendidikan jasmani. Pendidikan jasmani merupakan salah satu mata pelajaran yang wajib diberikan mulai dari jenjang pendidikan dasar hingga pendidikan menengah atas.Hal ini sekaligus sebagai bukti pentingya pembelajaran pendidikan jasmani di sekolah dan sebagai penguat bahwa pendidikan jasmani memiliki peranan penting dalam kehidupan.

PP No 19 tahun 2005 mendefinisikan bahwa pendidikan jasmani adalah suatu proses pembelajaran melalui aktifitas jasmani yang didesain untuk meningkatkan kebugaran jasmani, mengembangkan keterampilan motorik, pengetahuan dan perilaku 
hidup sehat dan aktif, sikap sportif dan kecerdasan emosi.

Peraturan Pemerintah Republik Indonesia Nomor 74 tahun 2008 tentang guru, yakni sebagaimana tercantum dalam BAB I ketentuan umum pasal 1 ayat (1) yang dimaksud dengan guru adalah sebagai berikut :"guru adalah pendidik profesional dengan tugas utama mendidik, mengajar, membimbing, mengarahkan, melatih, menilai, dan mengevaluasi peserta didik pada pendidikan anak usia dini jalur pendidikan formal, pendidikan dasar, dan pendidikan menengah. Guru bermutu dan profesional menjadi dambaan anak didiknya".Ini berarti agar tujuan pendidikan dapat tercapai dengan baik salah satunya ditentukan oleh peran guru dalam melaksanakan tugasnya dalam mengajar.

Bila dikaitkan dengan pendidikan jasmani dan olahraga, maka guru penjasorkes merupakan salah satu komponen penting yang mempunyai peranan yang sangat krusial dalam usaha meningkatkan sumber daya yang dihasilkan oleh suatu sekolah.Peranan dan tanggung jawab guru penjasorkesikut ambil bagian untuk meningkatkan kualitas manusia Indonesia.

Kinerja merupakan hasil kerja dan kemajuan yang telah dicapai seseorang dalam mencapai tugasnya.Kinerja guru penjasorkes merupakan hasil kerja guru penjasorkes dalam mencapai tugas utamanya yaitu mendidik, mengajar, membimbing dan melatih siswa. Tugas guru mencakup pengembangan program tahunan, program semester, pokok bahasan, program mingguan dan harian, program pengayaan dan remedial, serta program bimbingan dan konseling.Kinerja guru dalam pelaksanaan tugas seharusnya Mengikuti langkah-langkah yang sudah ditentukan, seperti halnya dalam pengelolaan pembelajaran, dimana seorang guru sebelum melaksanakan pengajaran didepan kelas, terlebih dahulu guru harus membuat persiapan pembelajaran, seperti : menyusun program pembelajaran tahunan,program semester, membuat silabus,membuat rencana pelaksanaan pembelajaran harian dan mingguan, selanjutnya melaksanakan pembelajaran dengan menggunakan berbagai metode, media dan sarana pembelajaran lainnya, selanjutnya guru harus melaksanakan evaluasi pembelajaran untuk mengukur kemampuan siswa dalam menguasai materi pelajaran yang telah diberikan dan terakhir seorang guru melakukan perbaikan dan pengayaan. Namun, dalam prakteknya, kinerja guru penjasorkesmasih rendah.

Berdasarkan pengamatan yang penulis lakukan di beberapa Sekolah Dasar Negeri Kecamatan Padang Utara Kota Padang selama bulan Januari 2016 dan pengamatanpenulis selama melakukan praktek lapangan kependidikan, diperoleh gambaran bahwa kinerja guru penjasorkes masih belum optimal.

Furtwengler dalam Torang (2013:74) mengemukakan bahwa "ada sebelas indikator dalam menilai kinerja individu, yaitu: (1) cepat dalam menyelesaikan pekerjaan, (2) kualitas kerja, (3) kualitas layanan, (4) nilai pekerjaan, 
(5) keterampilan interpersonal, keinginan untuk sukses, keterbukaan, (8) kreativitas, keterampilan berkomunikasi, inisiatif, (11) memiliki perencanaan". Dari beberapa uraian diatas dapat disimpulkan bahwa banyak indikator yang dapat digunakan untuk mengukur kinerja seorang guru dalam pelaksanaan tugasnya.Adapun indikator kinerja yang digunakan dalam penelitian ini adalah kualitas kerja, inisiatif, loyalitas dan kerjasama.

Istilah motivasi berasal dari perkataan bahasa latin yaitu Movere yang berarti menggerakkan. Dalam Kamus Besar Bahasa Indonesia dijelaskan bahwa "motivasi merupakan dorongan yang timbul pada diri seseorang secara sadar atau tidak sadar untuk melakukan suatu tindakan dengan tujuan tertentu".Dalam istilah motivasi tercakup berbagai aspek tingkah manusia yang mendorongnya untuk bertindak dan berbuat. Namun dalam uraian berikut ini, motivasi berarti pendorong manusia untuk bertindak dan berbuat. Usman (2009:250) menyebutkan bahwa "Motivasi kerja dapat diartikan sebagai keinginan atau kebutuhan yang melatarbelakangi seseorang sehingga ia terdorong untuk bekerja". Makawimbang (2012:178) menjelaskan bahwa "Motivasi kerja dalam psikologi kerja disebut pendorong semangat kerja. Motivasi kerja merupakan kemauan seorang pekerja yang ditimbulkan karena adanya dorongan dari dalam diri pekerja". Menurut Danang (2012:198)“Tujuan pemberian motivasi antara lain mendorong gairah dan semangat kerja guru, meningkatkan moral dan kepuasan kerja, meningkatkan produktivitas kerja guru, mempertahankan loyalitas dan kestabilan guru, meningkatkan kedisiplinan dan menurunkan absen guru, meningkatkan sarana dan hubungan kerja yang baik, meningkatkan kreatifitas dan partisipasi guru, meningkatkan kesejahtraan, mempertinggi tanggungjawab guru terhadap tugastugasnya".

Berdasarkan beberapa pendapat di atas, maka dapat disimpulkan motivasi kerja guru berarti daya dorong atau kemauan yang terdapat dalam diri seorangguru agar mau bekerja secara tekun serta bertanggungjawab dengan pekerjaannya agar tujuan yang diharapkan dapat tercapai.

Pentingnya motivasi kerja guru dikerenakan seorang guru untuk menjadi guru yang profesional harus memiliki motivasi kerja yang tinggi. Hal ini senada dengan pendapat Glickman dalam Bafadal (2009:5) yang menegaskan bahwa "Seorang guru dapat dikatakan profesional bilamana memiliki kemampuan tinggi dan motivasi kerja yang tinggi". Maksudnya adalah seorang guru akan bekerja secara profesional apabila memiliki kemampuan kerja yang tinggi dan kesungguhan hati untuk mengerjakan pekerjaan dengan sebaik-baiknya. Betapun tingginya kemampuan seseorang ia tidak akan bekerja secara profesional apabila tidak memiliki motivasi kerja yang tinggi.

Faktor motivasional adalah hal-hal pendorong yang sifatnya intrinsik, yang berarti bersumber dalam diri seseorang, sedangkan yang dimaksud 
dengan faktor higiene atau pemeliharaan adalah faktor-faktor yang sifatnya ekstrinsik yang berarti bersumber dari luar diri seseorang, misalnya organisasi, tetapi turut menentukan prilaku seseorang dalam kehidupan kekaryaannya. Menurut Harzberg dikutip Siagian (1992:290) "Yang tergolong sebagai faktor motivasional antara lain, ialah : 1) Pekerjaan seseorang, 2) Keberhasilan yang diraih, 3) Kesempatan bertumbuh, 4) Kemajuan dalam karier dan pengakuan orang lain".

Wahjosumidjo (2001:44) "Tinggi rendahnya motivasi seseorang dalam bekerja dapat dilihat dari indikatorindikator dibawah ini:

1) Ketekunan, sama halnya dengan kesungguhan dalam bekerja bahwa setiap individu dalam bekerja hendaknya dapat melaksanakan tugas dan tanggungjawabnya dengan baik.

2) Semangat kerja adalah sikap individu dan kelompok terhadap situasi pekerjaan dan kerelaan bekerjasama.

3) Disiplin kerja adalah suatu kepatuhan terhadap aturan aturan, norma-norma, hukum, tata tertib dan lain-lain.

4) Tanggungjawab adalah kesanggupan pegawai untuk menyelesaikan pekerjaan dengan baik dan tepat waktu".

Berdasarkan fenomena tentang kinerja dan motivasi kerja guru penjasorkesdiatas, tampaknya kinerja dan motivasi kerja guru penjasorkes belum sesuai dengan apa yang diharapkan. Hal ini terindikasi dari perilaku yang dimunculkan guru dalam pelaksanaan tugasnya. Kinerja guru yang rendah diduga karena rendahnya motivasi kerja yang ada pada guru. Tujuan dari penelitian ini adalah untuk mendapatkan informasi tentang hubungan motivasi kerja dan kinerja guru penjasorkesdalam pengelolaan pembelajaran di sekolah dasar negeri Kecamatan Padang Utara Kota Padang.

\section{METODE}

Penelitian ini merupakan sebuah penelitian yang berjenis penelitian korelasional. Berdasarkan tujuan penelitian yang telah dirumuskan, bahwa penelitian ini bertujuan untuk melihat Hubungan Motivasi Kerja dengan Kinerja Guru Penjasorkesdalam Pengelolaan Pembelajaran di Sekolah Dasar Negeri Kecamatan Padang Utara Kota Padang. Adapun metode penelitian yang digunakan dalam penelitian ini adalah metode penelitian kuantitatif.

Tempat penelitian dilakukan di Sekolah Dasar Negeri Kecamatan Padang Utara Kota Padang. Waktu penelitian ini direncanakan pada jam dinas Sekolah ketika diluar jam belajar Penjasorkes di semester Satu (JuliDesember) 2016, bertepatan pada Tanggal 29 Juli - 11 Agustus 2016 di Sekolah Dasar Negeri Kecamatan Padang Utara Kota Padang.Populasi yang digunakan dalam penelitian ini adalah seluruh guru Penjasorkes di Sekolah Dasar Negeri Kecamatan Padang Utara Kota Padang yang berjumlah 25 orang. Dalam penelitian ini, jumlah populasi penelitian sebanyak 25 orang. Sampel dalam penelitian ini adalah sebanyak 25 orang guru penjasorkes.Penelitian ini terdiri dari dua variabel yaitu kinerja 
guru penjasorkes sebagai variabel terikat/dependen $(\mathrm{Y})$ dan motivasi kerja guru penjasorkes sebagai variabel bebas/ independen (X).Pengumpulan data dilakukan sendiri oleh penulis. Alat pengumpulan data yang digunakan dalam penelitian ini adalah angket/kuesioner. Menurut Sugiyono (2011: 151),"Angket adalah teknik pengumpulan data yang dilakukan dengan cara memberi seperangkat pertanyaan atau pernyataan tertulis kepada reponden untuk dijawabnya. Angket disusun dengan model skala likert yang terdiri atas 5 alternatif jawaban yaitu SL (selalu), SR (sering), KD (kadang-kadang), JR (jarang), TP (tidak pernah). Untuk pernyataan positif diberi skor masing-masing secara berturut-turut adalah 5,4,3,2,1 dan untuk pernyataan negatif diberi skor masing-masing secara berturutturut 1,2,3,4,5". Untuk melihat hubungan motivasi kerja dengan kinerja guru di Sekolah Dasar Negeri Kecamatan Padang Utara Kota Padang, maka dilakukan analisis data dengan menggunakan teknik korelasi product moment.

\section{HASIL dan PEMBAHASAN}

Data yang akan dikemukakan yaitu hasil dari penelitian yang berkaitan dengan hubungan motivasi kerja dengan kinerja guru penjasorkes dalam pengelolaan pembelajaran di sekolah dasar negeri kecamatan padang utara kota padang. Jumlah populasi sasaran atau sampel pada penelitian ini adalah 25 (dua puluh lima) Sekolah Dasar Negeri di Kecamatan Padang Utara Kota Padang. Setiap sampel masing-masing terdiri dari dua responden yaitu kepala sekolah dan guru penjasorkes. Dari 25 (dua puluh lima) sampel tersebut, sebanyak satu sekolah menolak untuk mengisi kuesioner dengan alasan tidak ada guru penjasorkes di semester ini, satu sekolah menolak karena tidak diberi izin oleh kepala sekolah, dan ada tiga sekolah yang bergabung menjadi satu sekolah. Sehingga kuesioner yang dapat disebarkan hanya 21 sekolah.Terlihat bahwa responden mengisi dan mengembalikan kuesioner dengan responrate sebesar $84,00 \%$.Kuesioner diantarkan dan dijemput langsung kepada responden penelitian.

Hasil analisis deskriptif data Motivasi kerja Guru Penjasorkes di Sekolah Dasar Negeri Kecamatan Padang Utara Kota Padang diperoleh informasi bahwa secara rata-rata skor variabel Motivasi kerja guru penjasorkes dalam pengelolaan pembelajaran di Sekolah Dasar Negeri Kecamatan Padang Utara Kota Padang adalah 4,13 ini menunjukkan bahwa rata-rata guru sering memiliki Motivasi kerja kerja yang baik dan dengan tingkat pencapaian jawaban responden sebesar $82,69 \%$. Hal ini menunjukkan bahwa Motivasi Kerja Guru penjasorkes dalam pengelolaan pembelajaran di Sekolah Dasar Negeri Kecamatan Padang Utara Kota Padang masuk dalam kategori baik.

Jika diuraikan perindikator, maka dapat diungkapkan sebagai berikut:Indikator pertama yaitu ketekunan, Secara ratarata guru penjasorkes dalam pengelolaan pembelajaran di Sekolah Dasar Negeri Kecamatan Padang Utara Kota Padang memiliki ketekunan sebesar 4,04, sedangkan tingkat 
capaian responden atas indikator ketekunan sebesar $80,76 \%$. Hal ini berarti ketekunan guru masuk ke dalam kategori baik.Indikator kedua Semangat kerja, Secara rata-rata guru penjasorkes dalam pengelolaan pembelajaran di Sekolah Dasar Negeri Kecamatan Padang Utara Kota Padang memiliki semangat kerja dalam menyelesaikan pekerjaannya sebesar 4,24, sedangkan tingkat capaian responden atas indikator semangat kerja sebesar $84,86 \%$. Hal ini berarti semangat kerja masuk ke dalam kategori baik.Indikator ketiga disiplin, Secara rata-rata guru penjasorkes dalam pengelolaan pembelajaran di Sekolah Dasar Negeri Kecamatan Padang Utara Kota Padang mempunyai disiplin dalam menyelesaikan pekerjaannya sebesar 4,06, sedangkan tingkat capaian responden atas indikator disiplin sebesar 81,24\%. Hal ini berarti disiplin masuk ke dalam kategori baik.Indikator keempat tanggung jawab. Secara ratarata guru penjasorkes dalam pengelolaan pembelajaran di Sekolah Dasar Negeri Kecamatan Padang Utara Kota Padang mempunyai tanggung jawab dalam menyelesaikan pekerjaannya sebesar 4,20, sedangkan tingkat capaian responden atas indikator disiplin sebesar $83,90 \%$. $\mathrm{Hal}$ ini berarti tanggung jawab masuk ke dalam kategori baik.

Dari empat indikator dalam variabel Motivasi kerja Guru penjasorkes dalam pengelolaan pembelajaran di Sekolah Dasar Negeri Kecamatan Padang Utara Kota Padang, semua indikator masuk dalam kategori baik. Artinya Motivasi kerja Guru guru penjasorkes dalam pengelolaan pembelajaran di Sekolah Dasar Negeri Kecamatan Padang Utara Kota Padang diukur dengan empat indikator ini, sudah mencapai Motivasi kerja guru yang diinginkan dan diharapkan.

Hasil analisis deskriptif data Kinerja Guru Penjasorkes di Sekolah Dasar Negeri Kecamatan Padang Utara Kota Padang diperoleh informasi bahwa secara rata-rata skor variabel Kinerja guru penjasorkes dalam pengelolaan pembelajaran di Sekolah Dasar Negeri Kecamatan Padang Utara Kota Padang adalah 4,05 ini menunjukkan bahwa rata-rata guru sering memiliki Kinerja kerja yang baik dan dengan tingkat pencapaian jawaban responden sebesar $81,02 \%$. Hal ini menunjukkan bahwa Kinerja Gurupenjasorkes dalam pengelolaan pembelajaran di Sekolah Dasar Negeri Kecamatan Padang Utara Kota Padang masuk dalam kategori baik.

Jika diuraikan perindikator, maka dapat diungkapkan sebagai berikut: Indikator pertama yaitu kualitas kerja, Secara rata-rata guru penjasorkes dalam pengelolaan pembelajaran di Sekolah Dasar Negeri Kecamatan Padang Utara Kota Padang memiliki kualitas kerja sebesar 4,18, sedangkan tingkat capaian responden atas indikator kualitas kerja sebesar $83,52 \%$. Hal ini berarti kualitas kerja guru masuk ke dalam kategori baik.Indikator kedua Inisiatif, Secara rata-rataguru penjasorkes dalam pengelolaan pembelajaran di Sekolah Dasar Negeri Kecamatan Padang Utara Kota Padang memiliki inisiatif dalam menyelesaikan pekerjaannya sebesar 3,95, sedangkan tingkat capaian 
responden atas indikator inisiatif sebesar 78,95\%. Hal ini berarti inisiatif masuk ke dalam kategori cukup.Indikator ketiga loyalitas, Secara rata-rataguru penjasorkes dalam pengelolaan pembelajaran di Sekolah Dasar Negeri Kecamatan Padang Utara Kota Padang mempunyai loyalitas dalam menyelesaikan pekerjaannya sebesar 4,08, sedangkan tingkat capaian responden atas indikator loyalitas sebesar $81,52 \%$. Hal ini berarti loyalitas masuk ke dalam kategori baik.Indikator keempat kerjasama, Secara ratarataguru penjasorkes dalam pengelolaan pembelajaran di Sekolah Dasar Negeri Kecamatan Padang Utara Kota Padang mempunyai kerjasama dalam menyelesaikan pekerjaannya sebesar 4,00, sedangkan tingkat capaian responden atas indikator loyalitas sebesar $80,10 \%$. Hal ini berarti kerjasama masuk ke dalam kategori baik.

Dari empat indikator dalam variabel Kinerja Guru penjasorkes dalam pengelolaan pembelajaran di Sekolah Dasar Negeri Kecamatan Padang Utara Kota Padang, tiga indikator masuk dalam kategori baik dan satu indikator masuk dalam kategori cukup. Artinya Kinerja Guru Penjasorkes dalam pengelolaan pembelajaran di Sekolah Dasar Negeri Kecamatan Padang Utara Kota Padang diukur dengan empat indikator ini, sudah mencapai Kinerja guru yang diinginkan dan diharapkan.

Analisis uji normalitas dalam penelitian bertujuan untuk menguji asumsi bahwa distribusi sampel dari data sampel mendekati normalitas populasi.
Pengujian normalitas penyebaran skor data dengan menggunakan Uji kolmogorov smirnov. Taraf signifikansi yang digunakan sebagai dasar menolak atau menerima keputusan normal atau tidaknya suatu distribusi data adalah $\alpha 0,05$. Hipotesis yang diajukan untuk normalitas ini adalah sebagai berikut: $\mathrm{H} 1$ : data populasi berdistribusi normal, $\mathrm{HO}$ : data populasi tidak berdistribusi normal. Dasar pengambilan keputusan: 1) Jika Skor Sig. > Signifikansi Alpha $(0,05)$ berarti H1 diterima, 2) Jika skor Sig. < Signifikansi Alpha $(0,05)$ berarti $\mathrm{H} 1$ ditolak.

Hasil perhitungan uji normalitas dapat dilihat bahwa skor Signifikansi untuk variabel Motivasi Kerja Guru (X) sebesar 0,642 dan variabel Kinerja Guru (Y) sebesar 0,264, sementara signifikansi alpha yang dipakai adalah 0,05. Berdasarkan landasan pengambilan keputusan di atas, Ho diterima dan $\mathrm{H} 1$ ditolak. Dengan demikian dapat dinyatakan bahwa data dari kedua variabel dalam penelitian ini sebarannya membentuk distribusi normal.

Hipotesis yang diajukan dalam penelitian ini adalah sebagai berikut: "Terdapat hubungan yang signifikan antara motivasi dan kinerja guru penjasorkes dalam pengelolaan pembelajaran di sekolah dasar negeri Kecamatan Padang Utara Kota Padang digunakan analisis korelasi. Hasil analisis hipotesismenunjukkan bahwa nilai koefisien korelasi antara Motivasi Kerja Guru (X) dengan Kinerja Guru (Y) adalah 0,790 (79,00\%) dengan harga keberartian probabilitas sebesar 0,000 pada taraf signifikan 
alpha 0,05 . Hal ini berarti bahwa nilai probabilitas sebesar $0,000<$ taraf alpha 0,05 , sehingga Ho ditolak dan $\mathrm{H} 1$ diterima. Dengan demikian dapat dinyatakan bahwa Motivasi Kerja Guru mempunyai hubungan positif dengan Kinerja Guru Penjasorkes dalam pengelolaan pembelajaran di Sekolah Dasar Negeri Kecamatan Padang Utara Kota Padang secara signifikan pada taraf kepercayaan $95 \%$.

Dari keterangan di atas juga diperoleh koefisien determinasi $\left(R^{2}\right)$ sebesar 0,624 . Hal ini menunjukkan bahwa besarnya kontribusi Motivasi Kerja Guru (X) dengan Kinerja Guru (Y) sebesar $62,40 \%$ dalam hal ini berarti $62,40 \%$ variabel Motivasi Kerja Guru (X) memberikan hubungan dengan Kinerja Guru (Y) sedangkan sisanya sebesar $37,60 \%$ dipengaruhi oleh variabel lain.

Untuk mengetahui persamaan regresi yang terbentuk, sebelumnya dilakukan uji-F untuk mengetahui apakah model regresi bisa dipakai untuk memprediksi ubahan Kinerja Guru (Y). Skor Fhitung sebesar 10,745 dengan keberartian probabilitas sebesar 0,000 pada taraf alpha 0,05 Karena nilai probabilitasnya $<0,05$ maka model regresi bisa dipakai untuk memprediksi ubahan Kinerja Guru (Y).Untuk memperoleh model persamaan keberartian garis regresi sederhanadiperoleh koefisien $a=1172,260$ dan $b=36,435$. Dengan demikian diperoleh model persamaan regresinya sebesar $Y=1172,260+$ 36,435X dimana:

1. Konstanta sebesar 1172,260 menyatakan bahwa jika tidak ada Motivasi Kerja Guru (X), maka Kinerja Guru (Y) Penjasorkes dalam pengelolaan pembelajaran di Sekolah Dasar Negeri Kecamatan Padang Utara Kota Padang yang tercapai adalah sebesar 1172,260.

2. Koefisien regresi sebesar 36,435 menyatakan bahwa jika variabel Motivasi Kerja Guru (X) ditingkatkan sebesar 1 satuan, maka akan mengakibatkan naiknya Kinerja Guru (Y) Penjasorkes dalam pengelolaan pembelajaran di Sekolah Dasar Negeri Kecamatan Padang Utara Kota Padang sebesar 36,435.

Berdasarkan tabel di atas, diketahui harga $t_{\text {hitung }}$ Motivasi Kerja Guru (X) sebesar 4,502 > dari $t_{\text {tabel }}$ 2,0639 dan harga keberartian probabilitas sebesar $0,000<0,05$, maka Ho ditolak dan $\mathrm{H} 1$ diterima. Hal ini berarti Motivasi Kerja Guru (X) berhubungan secara signifikan dengan Kinerja Guru (Y) Penjasorkes dalam pengelolaan pembelajaran di Sekolah Dasar Negeri Kecamatan Padang Utara Kota Padang.

Pembahasan dalam Hubungan Motivasi Kerja Guru dengan Kinerja Guru Penjasorkes dalam pengelolaan pembelajaran di Sekolah Dasar Negeri Kecamatan Padang Utara Kota Padang adalah sebesar 0,624. artinya apabila seorang guru menggunakan Motivasi Kerja Guru yang baik, maka akan menghasilkan kinerja guruyang baik pula. Besar kekuatan antara Motivasi Kerja Dengankinerja guru yaitu sebesar $62,40 \%$. Sedangkan sisanya $37,60 \%$ dipengaruhi oleh variable dan indikator lain.

Motivasi kerja sangat penting sebab seorang guru untuk menjadi guru yang profesional harus memiliki motivasi kerja yang tinggi. Hal ini senada 
dengan pendapat Glickman dalam Bafadal (2009:5) Yang menegaskan bahwa "seorang guru dapat dikatakan profesional bilamana memiliki kemampuan tinggi dan motivasi kerja yang tinggi". Maksudnya adalah seorang guru akan bekerja secara profesional apabila memiliki kemampuan kerja yang tinggi dan kesungguhan hati untuk mengerjakan pekerjaan dengan sebaik-baiknya. Betapun tingginya kemampuan seseorang ia tidak akan bekerja secara profesional apabila tidak memiliki motivasi kerja yang tinggi.Hal ini sejalan dengan penelitian yang dilakukan oleh John dalam Winardi (2001:2) menjelaskan bahwa "Motivasi untuk bekerja merupakan suatu istilah yang digunakan dalam bidang keorganisasian, guna menerangkan kekuatan-kekuatan yang terdapat di dalam diri seorang individu, yang menjadi penyebab timbulnya tingkat, arah dan persistensi upaya yang dilaksanakan serta bertanggungjawab dalam hal bekerja".

Kinerja yang baik akan sangat diperngaruhi oleh beberapa faktor baik yang bersumber dari dalam diri guru sendiri maupun yang bersumber dari luar diri guru. Setiap guru memiliki peran dan tanggung jawab baik secara mandiri maupun kolektif. Jika setiap guru memiliki kinerja yang tinggi dan menyelesaikan pekerjaan dengan baik sesuai dengan bidang tugas yang dipercayakan kepadanya, maka dapat memberikan dampak positif terhadap hasil belajar peserta didik yaitu hasil belajar yang memuaskan dan pada akhirnya dapat mencapai tujuan pendidikan.Pentingnya kinerja yang baik juga ditegaskan oleh Siagian (2002:168), bahwa "Pegawai yang memiliki kinerja yang baik akan berdampak positif bagi organisasi secara keseluruhan. Oleh sebab itu, guru sebagai pegawai dalam dunia pendidikan juga harus memiliki kinerja yang baik agar dapat membawa dampak positif bagi dunia pendidikan terutama bagi peserta didik sebagai objek pendidikan". Hal ini berarti, bahwa setiap guru dalam dunia pendidikan sangat diharapkan untuk memiliki kinerja yang baik dalam rangka pencapaian tujuan sekolah dan tujuan pendidikan nasional.

Seorang guru harus memiliki kinerja yang baik dalam pengelolaan pembelajaran. Untuk mewujudkan proses pembelajaran yang berkualitas diperlukan pengelolaan pembelajaran yang baik. Guru dituntut untuk memiliki kemampuan dalam mengelola pembelajaran seefektif mungkin agar tujuan pembelajaran yang telah ditetapkan dapat dicapai.

\section{KESIMPULAN}

Berdasarkan hasil analisis dan pembahasan pada Bab IV sebelumnya, maka dapat ditarik beberapa kesimpulan mengenai hubungan Motivasi Kerja dengan Kinerja Guru Penjasorkes dalam pengelolaan pembelajaran di Sekolah Dasar Negeri Kecamatan Padang Utara Kota Padang, antara lain: 1) Motivasi Kerja Guru mempunyai hubungan positif dengan Kinerja Guru Penjasorkes dalam pengelolaan pembelajaran di Sekolah Dasar Negeri Kecamatan Padang Utara Kota Padang", hal ini terlihat dari harga $t_{\text {hitung }}$ Motivasi Kerja Guru (X) sebesar 4,502 
$>$ dari $t_{\text {tabel }} 2,0639$ dan harga keberartian probabilitas sebesar 0,000 $<0,05.2)$ Besarnya hubungan Motivasi Kerja Guru (X) dengan Kinerja Guru (Y) sebesar $62,40 \%$, dalam hal ini berarti $62,40 \%$ variabel Motivasi Kerja Guru (X) memberikan hubungan dengan Kinerja Guru (Y) sedangkan sisanya sebesar $37,60 \%$ dipengaruhi oleh variabel dan indikator lainnya.

Berdasarkan kesimpulan sebelumnya, maka untuk dapat meningkatkan Kinerja Guru Penjasorkes dalam pengelolaan pembelajaran di Sekolah Dasar Negeri Kecamatan Padang Utara Kota Padang maka dapat diberikan beberapa saran. Antara lain: 1) Kepada para guru Penjasorkes dalam pengelolaan pembelajaran di Sekolah Dasar Negeri Kecamatan Padang Utara Kota Padang untuk dapat meningkatkan lagi motivasi kerja. Karena jika motivasi kerja guru Penjasorkes dalam pengelolaan pembelajaran di Sekolah Dasar Negeri Kecamatan Padang Utara Kota Padang tersebut baik maka akan menghasilkan tingkat kinerja guru yang baik pula.2) Kepada para Kepala Sekolah di Sekolah Dasar Negeri Kecamatan Padang Utara Kota Padang untuk dapat memberikan arahan serta dorongan kepada guru penjasorkes dalam peningkatan motivasi kerja dalam pengelolaan pembelajaran di Sekolah Dasar Negeri Kecamatan Padang Utara Kota Padang.

\section{DAFTAR RUJUKAN}

Bafadal, Ibrahim.

2009. PeningkatanProfesionalisme

Guru SekolahDasar. Jakarta:

BumiAksara.

Danang, $\quad$ Sunyoto. 2012.

ManajemenSumberDayaManusia.

Yokyakarta : CAPS.

Makawimbang, Jerry. 2012.

KepemimpinanPendidikan yang

Bermutu. Bandung: Alfabeta.

PeraturanPemerintahRepublik

Indonesia Nomor 74 Tahun 2008

Tentang Guru

Permendiknas No. 41 Tahun

2007.Standar Proses

untukSatuanPendidikanDasardanMen

engah

PP No 19 tahun 2005

Siagian P. Sondang. 1992.

ManajemenSumberDayaManusia.

Jakarta: BumiAksara.

Siagian, P Sondang. 2002.

TeoridanPraktekKepemimpinan.

Jakarta: RinekaCipta

Sugiyono. 2011.

StatistikauntukPenelitian. Bandung:

Alfabeta.

Torang, Syamsir. 2013.

Organisasi\&Manajemen. Bandung

:Alfabeta.

Undang-UndangRepublik Indonesia

$\begin{array}{lll}\text { No. } & 20 & \text { Tahun } \\ 2003\end{array}$

tentangSistemPendidikanNasional

Usman, Husaini. 2009. Manajemen,

Teori,

PraktikdanRisetPendidikan.Jakarta:

BumiAksara.

Wahjosumidjo.

2001.

KepemimpinandanMotivasi. Jakarta:

Ghalia Indonesi 
Jurnal Menssana

ISSN :2527-645X

Vol. 2, No. 1, Mei 2017 